\title{
Endophytic mycobiota of wild medicinal plants from New Valley Governorate, Egypt and quantitative assessment of their cell wall degrading enzymes
}

\author{
Abdel-Sater MA ${ }^{1}$, Abdel-Latif AMA ${ }^{2,}$ Abdel-Wahab DA ${ }^{2}$ and Al-Bedak OA $^{3^{*}}$ \\ ${ }^{1}$ Department of Botany and Microbiology, Faculty of Science, Assiut University, Assiut 71511, Egypt \\ ${ }^{2}$ Department of Botany, Faculty of Science, New Valley University, El-Kharga, 72511, Egypt \\ ${ }^{3}$ Assiut University Mycological Centre, Assiut University, Assiut 71511, Egypt
}

Abdel-Sater MA, Ayat MA Abdel-Latif, Dalia A Abdel-Wahab, Al-Bedak OA 2021 - Endophytic mycobiota in some wild medicinal plants at New Valley Governorate, Egypt, and their cell wall degrading enzymes, Studies in Fungi 6(1), 78-91, Doi 10.5943/sif/6/1/4

\begin{abstract}
The present study isolated and identified 32 species of endophytic mycobiota belonging to 18 genera associated with 8 wild medicinal plants collected from El-Kharga Oasis, New Valley Governorate, Egypt. Fusarium was the most common genus followed by Alternaria and Aspergillus. Convolvulus arvensis was the plant with the highest number of endophytes over the other plant species, while Moringa oleifera reported the lowest number of endophytes. In addition, the entomopathogenic fungus Beauveria bassiana; was recorded for the first time from leaves of Portulaca oleracea. One hundred and twenty-three isolates representing 32 species were screened for their abilities to produce pectinase, carboxy methyl cellulase (CMCase) and avicellase enzymes on sucrose free- $\mathrm{Cz}$ supplemented, individually with $1 \%$ pectin or $1 \% \mathrm{CMC}$ or $1 \%$ avicel as a sole carbon source, respectively. Ninety-four isolates produced pectinase while 66 isolates produced cellulases. The quantitative assays of the three enzymes for high-producers were performed in submerged fermentation using sucrose-free $\mathrm{Cz}$ broth. Aspergillus was the superior in the production of the three enzymes with the potent strains were A. terreus AUMC 14287 for CMCase (22.0 $\mathrm{IU} / \mathrm{ml} / \mathrm{min})$ and avicellase $(47.868 \mathrm{IU} / \mathrm{ml} / \mathrm{min})$ and A. terreus AUMC 14278 for pectinase (225.43 $\mathrm{IU} / \mathrm{ml} / \mathrm{min})$.
\end{abstract}

Kew words - cellulose - endophytic fungi - medicinal plants - pectinase - submerged fermentation

\section{Introduction}

Endophytic microorganisms colonize in plant tissues in which they spend part or all their life cycle without causing disease symptoms in the host (Petrini 1991). Fungal endophytes may inhabit in different organs of the host including leaves, stems, bark, roots, fruits, flowers and seeds (Rodriguez et al. 2009). Generally, in this symbiotic relationship fungal endophytes receive shelter and nutrients from the host, while the host plant may benefit from an array of attributes which include protection against natural enemies such as pathogens and herbivores (Schardl et al. 2004, Singh et al. 2011), plant growth promotion (Hamayun et al. 2010) and increasing the resistance of plants to abiotic stresses such as salinity and heavy metal toxicity in soil (Khan et al. 2014). Some medicinal plants are known for harboring endophytic fungi, which are important sources of various 
bioactive secondary metabolites and enzymes valuable for the pharmaceutical industry (Zou et al. 2000, Strobel et al. 2004, Krishnamurthy et al. 2008).

Endophytic fungi are relatively unexplored producers of metabolites useful in pharmaceutical and agricultural industries. A single endophyte can produce several bioactive metabolites. As a result, the role of endophytes in the production of various natural products with greater bioactivity have received increased attention (Prabavathy \& Valli 2012). Pectinases and cellulases, besides other enzymes, are the most important enzymes produced by endophytic fungi as a resistance mechanism against pathogenic invasion and to obtain nutrition from the host. These enzymes have various industrial applications, thus of major interest. Increasing efforts are being taken to characterize and identify endophytic fungi from medicinal plants. Therefore, the present work was designed to study the biodiversity of endophytic fungi in some wild medicinal plants from the New Valley Governorate, Egypt, and to evaluate their ability to produce extracellular pectinases and cellulases.

\section{Materials and methods}

\section{Sampling area}

The New Valley Governorate is located at the Western Desert of Egypt. It encompasses $440,098 \mathrm{~km}^{2}$, which is approximately $44 \%$ of the total area of Egypt and $66 \%$ of the area of Western Sahara. It is demarcated by the Governorates of Minya, Assiut, Sohag, Qena and Aswan from the east, by Libya and the Governorates of Matrouh and the Marine Oasis of the $6^{\text {th }}$ of October City from the West and by Sudan from the South. The New Valley includes four large Oases namely El-Kharga (the sampling sites), El-Dakhla, El-Bahariya and El-Farafra, and the capital is El-Kharga (Fig. 1).
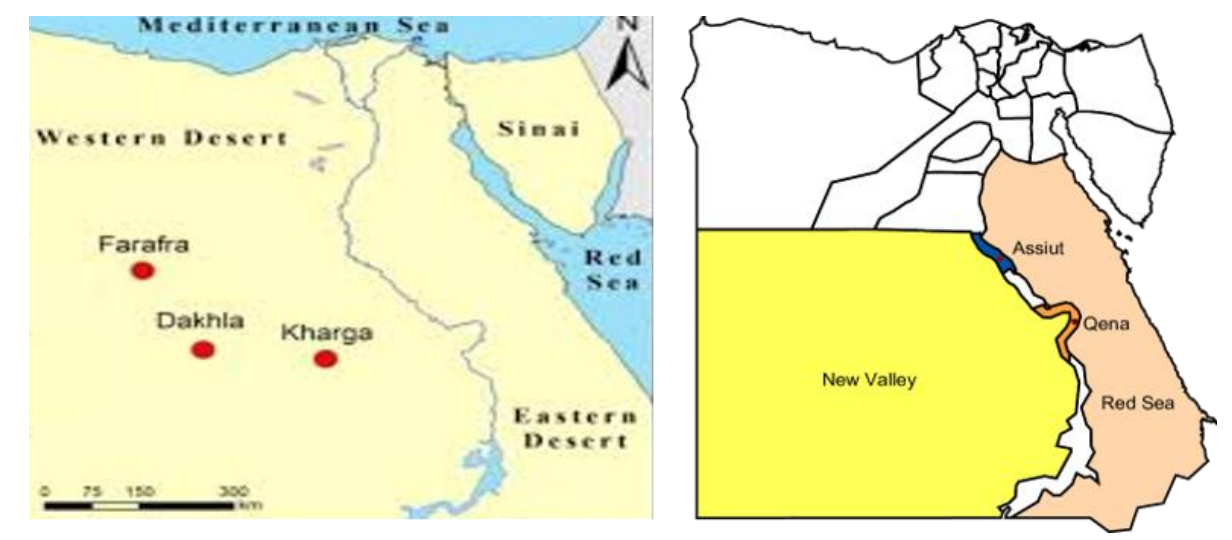

Fig. 1 - Location of the New Valley Governorate showing study site.

\section{Sample collection and identification of plant species}

Healthy and mature plant leaves and roots of eight wild medicinal plants were collected from El-Kharga Oasis, New Valley Governorate once during April 2018. Ten replicates from each of Alhagi graecorum, Anagallis arvensis, Calotropis procera, Chenopodium ambrosioides, Convolvulus arvensis, Moringa oleifera, Portulaca oleracea, and Ricinus communis plants were collected in sterile polyethylene bags and promptly brought to the laboratory for isolation of fungi. The plant species collected in the current investigation were identified according to morphological features and taxonomical characters at the Assiut University Herbarium, Department of Botany and Microbiology, Faculty of Science, Assiut University, Assiut, Egypt (Fig. 2).

\section{Sample preparation and surface sterilization}

Prior to surface sterilization, leaves and roots of each sample were thoroughly washed with tap water to remove the dust followed by distilled water. The samples were then cut into $5-\mathrm{cm}$ 
segments. The samples were surface sterilized using the following sequence; 5\% sodium hypochlorite for $3 \mathrm{~min}, 70 \%$ ethanol for $1 \mathrm{~min}$, and washing with sterile distilled water 3 times each for $1 \mathrm{~min}$. In aseptic conditions, both ends of each segment $(1 \mathrm{~cm})$ was cut off to produce a $3-\mathrm{cm}$ segments (Al-Bedak et al. 2020).

\section{Isolation of endophytic fungi}

Segments of each sample were plated on Petri-dishes containing $1 \%$ glucose-Cz with the following composition (g/l): Glucose, $10 ; \mathrm{Na}_{2} \mathrm{NO}_{3}, 2 ; \mathrm{K}_{2} \mathrm{HPO}_{4}, 1 ; \mathrm{KCl}, 0.5 ; \mathrm{MgSO}_{4} .7 \mathrm{H}_{2} \mathrm{O}, 0.5$; $\mathrm{FeSO}_{4}, 0.01 ; \mathrm{ZnSO}_{4}, 0.01 ; \mathrm{CuSO}_{4}, 0.005$; Rose Bengal, 0.05; chloramphenicol, 0.25; agar, 15 and the final $\mathrm{pH} 7.3$ (Ismail et al. 2017). The plates were incubated for $7-21$ days at $25^{\circ} \mathrm{C}$. Counts of CFUs of each fungal isolate were calculated per 25 segments in every sample. The obtained fungi were identified morphologically to the species level at the Assiut University Mycological Centre according to their macroscopic and microscopic characteristics. Pure cultures of the fungal strains were preserved for further investigations on PDA slants, as well as on cotton balls (Al-Bedak et al. 2019) at $4^{\circ} \mathrm{C}$ in the culture collection of the Assiut University Mycological Centre.

\section{Phenotypic identification of fungi}

The obtained fungi in this study were identified morphologically to the species level at the Assiut University Mycological Centre according to their macroscopic and microscopic characteristics. The following references were used for the identification of fungal genera and species (purely morphologically, based on macroscopic and microscopic features): Booth (1971), Ellis (1976), Pitt (1979), Domsch et al. (2007), Moubasher (1993), de Hoog et al. (2000), Samson et al. (2004), Leslie \& Summerell (2006), Simmons (2007) and Al-Bedak et al. (2020).

\section{Screening of pectinase and endoglucanase production on solid medium}

Production of pectinase and endoglucanase was detected on sucrose-free Czapek's agar medium amended with pectin (from citrus peel) and CMC as a sole carbon source, respectively. 50 $\mu \mathrm{l}$ of spore suspension from 7-day-old culture of each fungal strain was individually added to each 5-mm diameter well on the agar plate (Moubasher et al. 2016). The inoculated plates were incubated for 2 days at $30^{\circ} \mathrm{C}$. The clear zones formed around the wells were more visible when the plates were flooded with $0.25 \%(\mathrm{w} / \mathrm{v})$ aqueous iodine solution. The diameters of the clear zones were measured (in $\mathrm{mm}$ ) against the brown color of the test medium indicating enzyme production.

\section{Production of pectinases and cellulases under submerged fermentation}

All positive fungal strains were grown, individually in 250-ml Erlenmeyer conical flasks each containing $50 \mathrm{ml}$ sucrose-free Czapek's broth medium supplemented with $1 \%$ pectin or $1 \%$ $\mathrm{CMC}$ as sole carbon source. The flasks were then inoculated individually with $1 \mathrm{ml}$ spore suspension containing $1 \times 10^{7}$ spore/ml of 7-day-old culture of the tested strains. The inoculated flasks were then incubated at $30^{\circ} \mathrm{C}$ in shaking condition of $150 \mathrm{rpm}$ for 7 days.

\section{Enzyme extraction}

After incubation period, the flasks contents were individually filtered through filter papers (Whatman No. 1) and the filtrate was then centrifuged at $10000 \mathrm{xg}$ for $10 \mathrm{~min}$ at $4^{\circ} \mathrm{C}$. The clear supernatants were used as a source for CMCase or pectinase enzyme.

\section{Pectinase assay}

The enzyme production was determined by mixing $0.9 \mathrm{ml}$ of $1 \%$ pectin (prepared in $50 \mathrm{mM}$ Na-citrate buffer, pH 5.0) with $0.1 \mathrm{ml}$ of filtered crude enzyme, and the mixture was incubated at $50^{\circ} \mathrm{C}$ for $15 \mathrm{~min}$ in a water bath (Bailey et al. 1992). The reaction was stopped by the addition of 2 $\mathrm{ml}$ of 3,5-dinitrosalicylic acid (DNS) and the contents were boiled in water bath for $10 \mathrm{~min}$ (Miller 1959). After cooling, absorbance was measured at $540 \mathrm{~nm}$ using Cary $60 \mathrm{UV}$-Vis spectrophotometer. The amount of reducing sugar liberated was quantified using calibration curve 
of glucose. One unit of pectinase is defined as the amount of enzyme that liberates $1 \mu$ mol of glucose equivalents per minute under the standard assay conditions.

\section{Cellulases (CMCase and avicellase) assay}

The cellulases activity was determined by mixing $0.9 \mathrm{ml}$ of $1 \% \mathrm{CMC}$ or $1 \%$ avicel (prepared in $50 \mathrm{mM} \mathrm{Na}$-citrate buffer, $\mathrm{pH} 5.0$ ) with $0.1 \mathrm{ml}$ of filtered crude enzyme, and the mixture was incubated at $50^{\circ} \mathrm{C}$ for $15 \mathrm{~min}$ in a water bath (Bailey et al. 1992). The reaction was stopped by the addition of $2 \mathrm{ml}$ of 3,5-dinitrosalicylic acid (DNS) and the contents were boiled in water bath for 10 min (Miller 1959). After cooling, absorbance of the developed color was measured at $540 \mathrm{~nm}$ using Cary $60 \mathrm{UV}-\mathrm{Vis}$ spectrophotometer. The amount of reducing sugar liberated was quantified using calibration curve of glucose. One unit of CMCase or avicellase is defined as the amount of enzyme that liberates $1 \mu \mathrm{mol}$ of glucose equivalents per minute under the standard assay conditions. Glucose concentration was calculated using the calibration curve.

$$
\begin{aligned}
\text { Glucose concentration } & =\frac{\text { Absorbance }}{\text { slope }(=1.0472)} \mathrm{mg} / \mathrm{ml}(=\mathrm{g} / \mathrm{L}) \\
\text { Enzyme concentration } & =\frac{\text { Glucose concentration }(\mathrm{g} / \mathrm{L})}{0.00018} \mathrm{IU} / \mathrm{L}
\end{aligned}
$$

The enzyme activity (pectinase or CMCase or avicellase) was calculated according to the following formula (Moubasher et al. 2016)

$$
\text { Enzyme activity }=\text { Absorbance x DF x }\left(\frac{1}{x}\right)\left(\frac{1}{y}\right)\left(\frac{1}{t}\right)\left(\frac{1}{\text { slope }}\right)
$$

Where: DF $=$ the dilution factor for enzyme, $x=$ the volume of enzyme used, $y=$ the volume of hydrolysate used for assay of reducing sugars, $t=$ the time of hydrolysis, slope is determined from a standard curve

\section{Results}

\section{Biodiversity of endophytic fungi}

A total of 32 species related to 18 genera of endophytic mycobiota were recovered on $1 \%$ glucose- $\mathrm{Cz}$ at $25^{\circ} \mathrm{C}$ from healthy and mature plant leaves and roots of eight wild medicinal plants, collected from El-Kharga Oasis, the New Valley Governorate. The high incidence in genera were recorded in Alternaria, Aspergillus and Fusarium. Fusarium (represented by 2 species) was the most common and encountered total CFU constituting $37.0 \%$ of total fungi. It was recovered from 7 plants out of 8. F. oxysporum was the most prevalent species encountering $23.1 \%$ of total fungi, however it was recorded from 3 plants only, followed by $F$. solani giving rise to $13.9 \%$ of total fungi and it was the most frequent recovered from 6 plants. Alternaria ( 7 species) came next to Fusarium and it was comprised $24.0 \%$ of total fungi with A. alternata being the most common Alternaria species recorded from 4 plants and was comprised $10.33 \%$ of total fungi followed by $A$. tenuissima (from 4 plants) comprising $7.42 \%$ of total fungi. Aspergillus (5 species in addition to 2 unknown species) was the runner of Alternaria comprising $17.5 \%$ of total fungi. It was the most frequent genus isolated from all the studied plants. The most prevalent Aspergillus species were A. terreus followed by A. flavus constituting $7.42 \%$ and $5.84 \%$ of total fungi respectively (Table 1).

Aspergillus parasiticus, Macrophomina phaseolina were found in 4 plant species, A. longipes and Stemphylium botryosum in 3 plants, A. citri, A. fumigatus, and C. spicifera in 2 plants while Acremonium rutilum, Beauveria bassiana, Chaetomium senegalense, Cladosporium exile, Clonostachys rosea, C. solani, Pseudoallescheria boydii, Rhizoctonia solani, Rhizopus microsporus, Scopulariopsis fimicola, Stemphylium botryosum and Verticillium fungicola were 
recorded each in one plant species. Convolvulus arvensis was the richest plant with endophytes containing 14 species belonged to 8 genera and recording the highest CFUs of 79 per 25 segments over the remaining plant species, while Moringa oleifera was the poorest in endophytes with 5 species belonging to 2 genera and the lowest CFUs of 13 per 25 segments. It is worth mentioning that Beauveria bassiana; the known entomopathogenic fungus was recorded for the first time from leaves of Portulaca oleracea as an endophyte (Table 1).

\section{Preliminary screening of endophytic fungi for pectinases and cellulases production}

One-hundred and twenty fungal isolates representing 31 species related to 17 genera of endophytic fungi were screened for their abilities to produce pectinase and endoglucanase on sucrose free-Cz supplemented with $1 \%$ pectin or $1 \% \mathrm{CMC}$ as a sole carbon source, respectively. Ninety-four isolates could produce pectinase enzyme, of which 18 were high producers, 25 moderate and 51 low. 66 isolates could produce cellulase, of which 13 were high producers, 16 moderate and 37 low (Appendix 1).

\section{Submerged production of pectinases and cellulases (CMCase and avicellase)}

The quantitative assay of pectinase, CMCase and avicellase for high-producing isolates were performed in submerged fermentation using sucrose-free $\mathrm{Cz}$ broth medium amended with $1 \%$ pectin or CMC or avicel as the sole carbon source. Of these, 17 isolates could produce pectinase enzyme with a relative activity ranged from $147.84 \mathrm{IU} / \mathrm{ml} / \mathrm{min}$ to $225.43 \mathrm{IU} / \mathrm{ml} / \mathrm{min}$ while 14 could produce CMCase $(1.84 \mathrm{IU} / \mathrm{ml} / \mathrm{min}-22.0 \mathrm{IU} / \mathrm{ml} / \mathrm{min})$ and avicellase $(26.0 \mathrm{IU} / \mathrm{ml} / \mathrm{min}-47.87$ $\mathrm{IU} / \mathrm{ml} / \mathrm{min}$ ). Six isolates were found to have the abilities to produce the three enzymes, of which Aspergillus was the superior with the potent strains were A. terreus AUMC 14278 for pectinase activity giving $225.43 \mathrm{IU} / \mathrm{ml} / \mathrm{min}$ and A. terreus AUMC 14287 for CMCase producing 22.0 $\mathrm{IU} / \mathrm{ml} / \mathrm{min}$ and avicellase recording $47.868 \mathrm{IU} / \mathrm{ml} / \mathrm{min}$ (Tables 2-4).

\section{Discussion}

In the current study, endophytic mycobiota in healthy and mature leaves and roots of eight wild medicinal plants were isolated on $1 \%$ glucose- $\mathrm{Cz}$ at $25^{\circ} \mathrm{C}$ from sample collected once in April 2018. This study is considered as the first in the New Valley Governorate, Egypt for evaluation of endophytic fungi from these medicinal plants. There is a growing body of literatures that recognize the importance of endophytic fungi across a number of disciplines in recent years as biological sources of a wide range of valuable compounds including plant growth regulatory, antibacterial, antifungal, antiviral, insecticidal substances to enhance the growth and competitiveness of the host in nature (Anwar et al. 2007, Kaur \& Kalia 2012, Khairnar et al. 2012, Al-Snafi 2015, Muhammad et al. 2015, Syed et al. 2016, Khan Marwat et al. 2017).

The current results revealed that endophytic fungal assemblages were obtained from all plant species examined and some plants were occupying by the same fungal genera and species, indicating that endophytic fungi can be the same in plants belonging to different families. Altogether, 32 species related to 18 genera were recovered from the leaves and roots of all tested plants.

The high occurrence genera where described by Fusarium, Aspergillus and Alternaria. Fusarium was the most widespread genus retrieved from 7 plants. F. oxysporum is the most dominant led by $F$. solani. Such latest observations have, to some degree, been compatible with the reports of Raviraja (2005) who researched endophytic fungi in five Brazilian medicinal plants and found that Aspergillus and Penicillium were isolated at high frequencies, however, Fusarium oxysporum was reported at low levels from leaves of two plants tested. Previous studies on plants of the same size as ours have previously been conducted with the genera Fusarium, Aspergillus, Nigrospora, Stachybotrys, Rhizoctonia and Macrophomina from Moringa leaves (Carbungco et al. 2015). Almost similar results were obtained in other studies on Calotropis procera in Karachi (Khan et al. 2007) or in Saudi Arabia (Gherbawy \& Gashgari 2014). 
Endophytic fungi produce enzymes such as amylases, cellulase, lipases and proteases, as part of their mechanism to overcome the defense of the host against microbial invasion and to obtain nutrients for their development (Patil et al. 2015). In addition, these enzymes are essential for endophytic fungi to colonize in the plant tissue (Sunitha et al. 2013). The array of enzymes produced differs between fungi and often depends on the host and their ecological factors (Sunitha et al. 2013). In the current study, 120 fungal isolates were screened for their ability to produce pectinase and cellulase. The results obtained revealed that $78.0 \%$ of the total isolates tested could produce pectinase enzyme and $55.0 \%$ could produce cellulase enzyme.

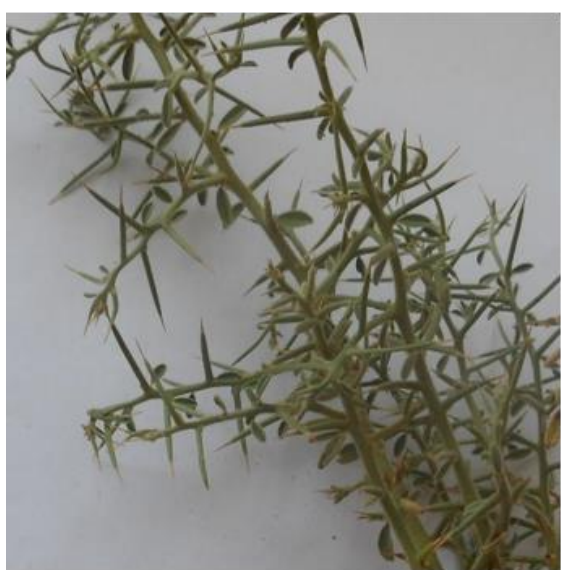

Alhagi graecorum

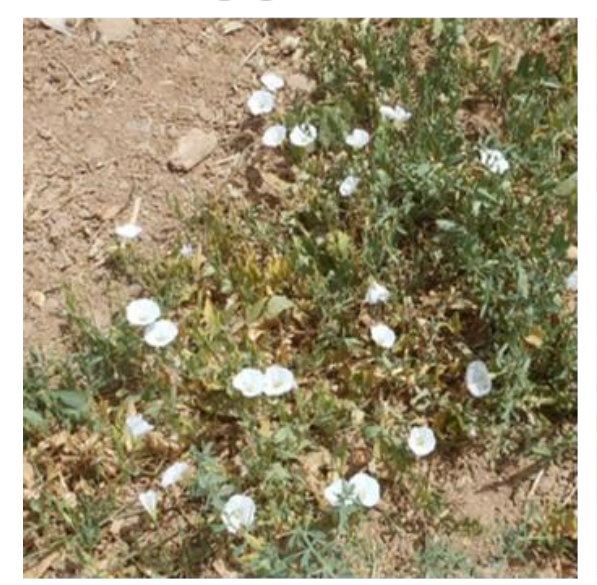

Convolvulus arvensis

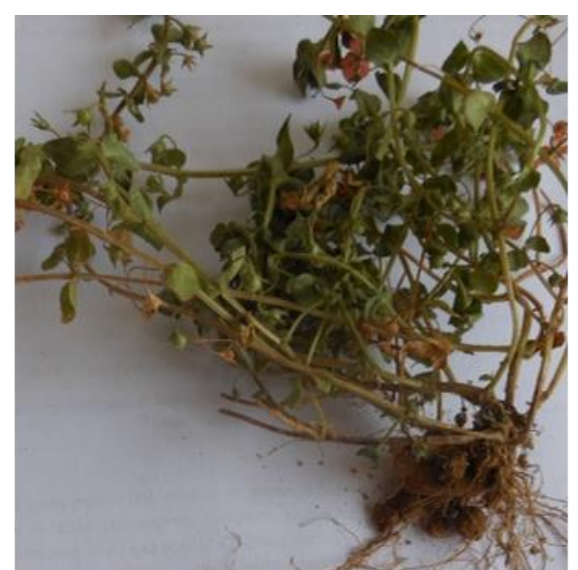

Anagallis arvensis

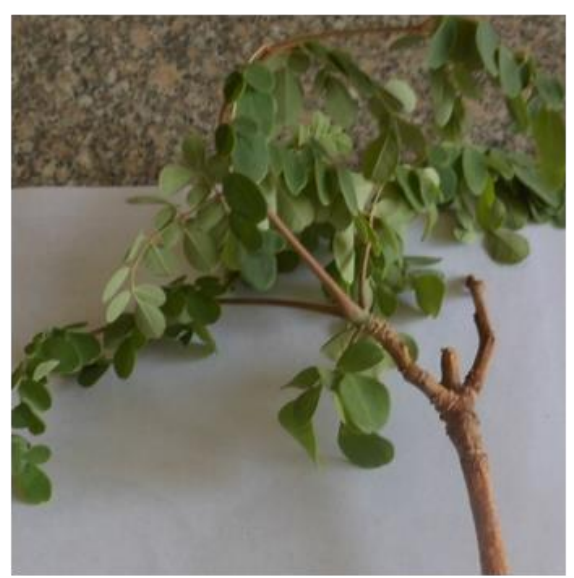

Moringa oleifera

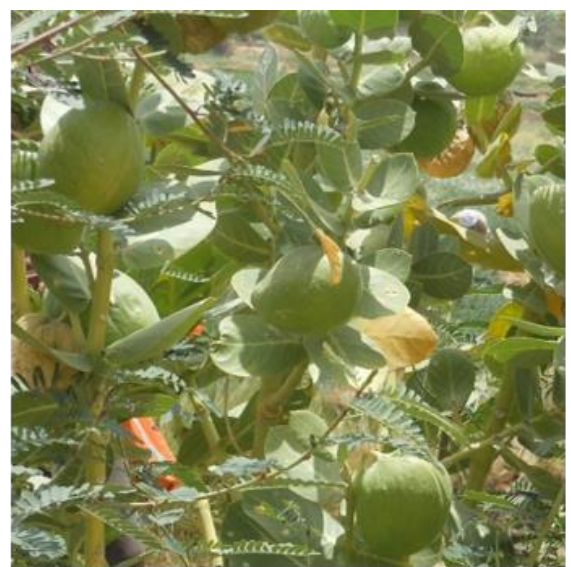

Calotropis procera

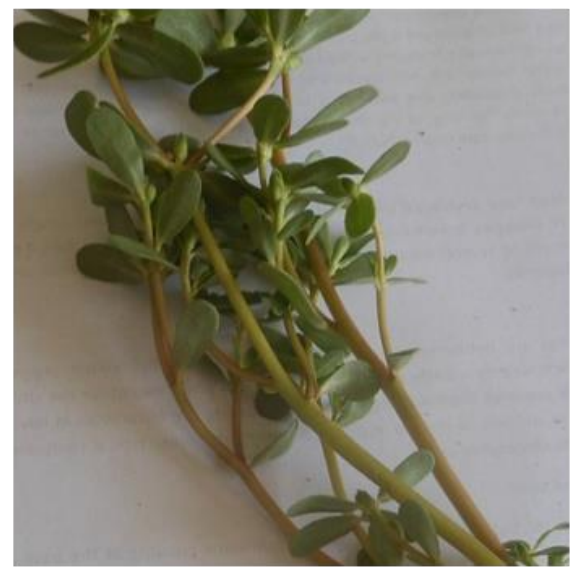

Portulaca oleracea

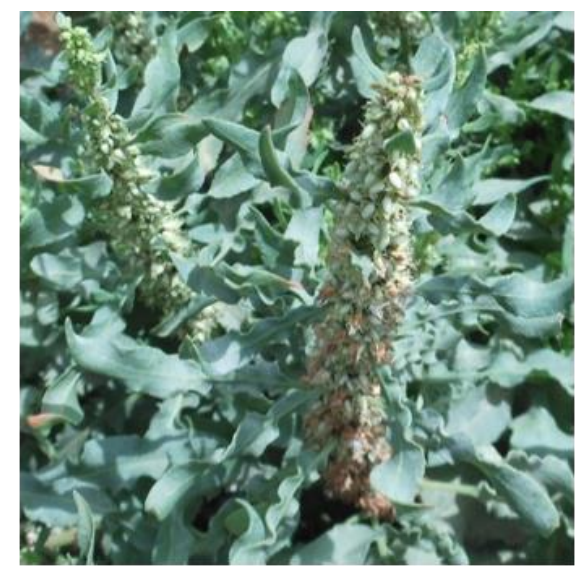

Chenopodium ambrosioides

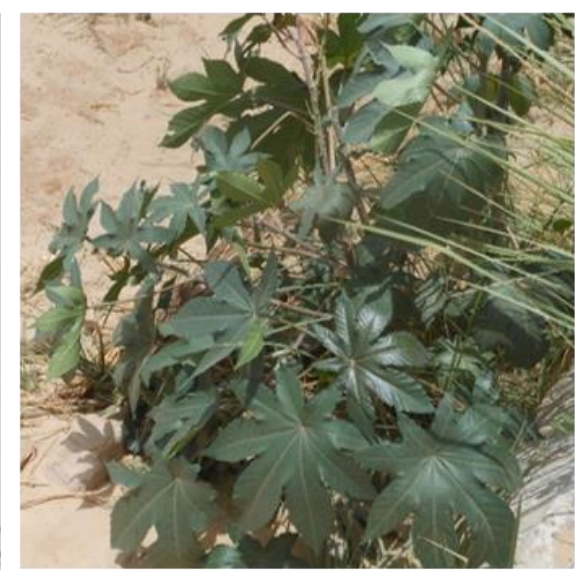

Ricinus communis

Fig. 2 - Wild medicinal plant species collected from El-Kharga Oasis, the New Valley Governorate, Egypt, during April 2018. 
Table 1 CFUs (calculated to the total CFUs of each fungus per 25 segments of leaves (L) or roots (R) of each plant sample), Gross total CFUs and \% gross total CFUs of fungi isolated from 8 wild medicinal plants collected from El-Kharga Oasis, New Valley Governorate on $1 \%$ glucose-Cz at $25^{\circ} \mathrm{C}$ during April 2018.

\begin{tabular}{|c|c|c|c|c|c|c|c|c|c|c|c|c|c|c|c|c|c|c|}
\hline \multirow{3}{*}{ Fungal genera $\&$ species } & \multicolumn{16}{|c|}{ Plant species } & \multirow{2}{*}{\multicolumn{2}{|c|}{ Gross total }} \\
\hline & \multicolumn{2}{|c|}{\begin{tabular}{|l|} 
Alhagi \\
graecorum
\end{tabular}} & \multicolumn{2}{|c|}{$\begin{array}{l}\text { Convolvulus } \\
\text { arvensis }\end{array}$} & \multicolumn{2}{|c|}{$\begin{array}{l}\text { Chenopodium } \\
\text { ambrosioides }\end{array}$} & \multicolumn{2}{|c|}{$\begin{array}{l}\text { Calotropis } \\
\text { procera }\end{array}$} & \multicolumn{2}{|c|}{$\begin{array}{l}\text { Ricinus } \\
\text { communis }\end{array}$} & \multicolumn{2}{|c|}{$\begin{array}{l}\text { Angallis } \\
\text { arvensis }\end{array}$} & \multicolumn{2}{|c|}{$\begin{array}{l}\text { Moringa } \\
\text { oleifera }\end{array}$} & \multicolumn{2}{|c|}{$\begin{array}{l}\text { Portulaca } \\
\text { oleracea }\end{array}$} & & \\
\hline & $\mathbf{L}$ & $\mathbf{R}$ & $\mathbf{L}$ & $\mathbf{R}$ & $\mathbf{L}$ & $\mathbf{R}$ & $\mathbf{L}$ & $\mathbf{R}$ & $\mathbf{L}$ & $\mathbf{R}$ & $\mathbf{L}$ & $\mathbf{R}$ & $\mathbf{L}$ & $\mathbf{R}$ & $\mathbf{L}$ & $\mathbf{R}$ & CFU & $\% \mathrm{CFU}$ \\
\hline Acremonium & & & 4 & & & & & & & & & & & & & & 4 & 0.89 \\
\hline A. rutilum & & & 1 & & & & & & & & & & & & & & 1 & 0.22 \\
\hline A. sclerotigenum & & & 3 & & & & & & & & & & & & & & 3 & 0.67 \\
\hline Alternaria & & & & 1 & 34 & & 36 & & & $\mathbf{1}$ & 20 & & 15 & & & & 107 & 24 \\
\hline A. alternata & & & & 1 & 21 & & 20 & & & & 4 & & & & & & 46 & 10.33 \\
\hline A. brassicicola & & & & & & & & & & 1 & & & & & & & 1 & 0.22 \\
\hline A. chlamydospora & & & & & & & & & & & & & 8 & & & & 8 & 1.79 \\
\hline A. citri & & & & & & & 1 & & & & 7 & & & & & & 8 & 1.79 \\
\hline A. citri macularis & & & & & & & 4 & & & & & & & & & & 4 & 0.89 \\
\hline A. longipes & & & & & 3 & & 3 & & & & & & 1 & & & & 7 & 1.57 \\
\hline A. tenuissima & & & & & 10 & & 8 & & & & 9 & & 6 & & & & 33 & 7.42 \\
\hline Aspergillus & 1 & 10 & 3 & 2 & 1 & 1 & 20 & 10 & 21 & 2 & 2 & & 2 & & 1 & 2 & 78 & 17.5 \\
\hline A. creber & & & 2 & & & & & & & & & & & & & & 2 & 0.44 \\
\hline A. flavus & & 1 & & 1 & & 1 & & & 19 & 2 & 1 & & & & & 1 & 26 & 5.84 \\
\hline A. fumigatus & & & & & 1 & & & & 1 & & & & & & & & 2 & 0.44 \\
\hline A. keveii & & & & & & & & & & & & & 1 & & & & 1 & 0.22 \\
\hline A. parasiticus & & & & 1 & & & & 8 & & & 1 & & & & 1 & 1 & 12 & 2.70 \\
\hline A. terreus & 1 & 9 & 1 & & & & 20 & & 1 & & & & 1 & & & & 33 & 7.42 \\
\hline A. tubingensis & & & & & & & & 2 & & & & & & & & & 2 & 0.44 \\
\hline Beauveria bassiana & & & & & & & & & & & & & & & 1 & & 1 & 0.22 \\
\hline Chaetomium senegalense & & & & & & & & 1 & & & & & & & & & 1 & 0.22 \\
\hline Cladosporium exile & & & & & & & & & 1 & & & & & & & & 1 & 0.22 \\
\hline Clonostachys solani & & & 1 & & & & & & & & & & & & & & 1 & 0.22 \\
\hline Curvularia spicifera & & 19 & & 1 & & & & & & & & & & & & & 20 & 4.49 \\
\hline Fusarium & & 7 & 33 & 37 & & 14 & & 12 & & 14 & 22 & 6 & & & & 20 & 165 & 37 \\
\hline F. oxysporum & & 6 & 33 & 36 & & & & & & & 22 & 6 & & & & & 103 & 23.1 \\
\hline$F$. solani & & 1 & & 1 & & 14 & & 12 & & 14 & & & & & & 20 & 62 & 13.9 \\
\hline Macrophomina phaseolina & & & & 1 & & 4 & & & & 1 & & 1 & & & & & 7 & 1.57 \\
\hline Penicillium olsonii & & & & & & & & & 21 & & & & & & & & 21 & 4.72 \\
\hline Pseudoallescheria boydii & & & & & & & & & & 2 & & & & & & & 2 & 0.44 \\
\hline Rhizoctonia solani & & & & & & & & & & & 1 & 2 & & & & & 3 & 0.66 \\
\hline
\end{tabular}


Table 1 Continued.

\begin{tabular}{|c|c|c|c|c|c|c|c|c|c|c|c|c|c|c|c|c|c|c|}
\hline \multirow{3}{*}{ Fungal genera \& species } & \multicolumn{16}{|c|}{ Plant species } & \multirow{3}{*}{\multicolumn{2}{|c|}{ Gross total }} \\
\hline & \multicolumn{2}{|c|}{$\begin{array}{l}\text { Alhagi } \\
\text { graecorum }\end{array}$} & \multicolumn{2}{|c|}{$\begin{array}{l}\text { Convolvulus } \\
\text { arvensis }\end{array}$} & \multicolumn{2}{|c|}{$\begin{array}{l}\text { Chenopodium } \\
\text { ambrosioides }\end{array}$} & \multicolumn{2}{|c|}{$\begin{array}{l}\text { Calotropis } \\
\text { procera }\end{array}$} & \multicolumn{2}{|c|}{$\begin{array}{l}\text { Ricinus } \\
\text { communis }\end{array}$} & \multicolumn{2}{|c|}{$\begin{array}{l}\text { Angallis } \\
\text { arvensis }\end{array}$} & \multicolumn{2}{|c|}{$\begin{array}{l}\text { Moringa } \\
\text { oleifera }\end{array}$} & \multicolumn{2}{|c|}{$\begin{array}{l}\text { Portulaca } \\
\text { oleracea }\end{array}$} & & \\
\hline & $\mathbf{L}$ & $\mathbf{R}$ & $\mathbf{L}$ & $\mathbf{R}$ & $\mathbf{L}$ & $\mathbf{R}$ & $\mathbf{L}$ & $\mathbf{R}$ & $\mathbf{L}$ & $\mathbf{R}$ & $\mathbf{L}$ & $\mathbf{R}$ & $\mathbf{L}$ & $\mathbf{R}$ & $\mathbf{L}$ & $\mathbf{R}$ & & \\
\hline Rhizopus microspores & & & & & & & & & & & & & & & & 1 & 1 & 0.22 \\
\hline Sarocladium kiliense & & & & 2 & & & & & & & & & & & & & 2 & 0.44 \\
\hline Scopulariopsis fimicola & & & & & 1 & & & & & & & & & & & & 1 & 0.22 \\
\hline Stemphylium botryosum & & & & & & & 6 & & 1 & & 6 & & & & & & 13 & 2.92 \\
\hline Verticillium fungicola & & & 2 & & & & & & & & & & & & & & 2 & 0.44 \\
\hline Yeast spp. & & 1 & & & & 1 & & & 1 & 1 & 1 & & 1 & & 8 & 1 & 15 & 3.37 \\
\hline CFUs & 1 & 37 & 43 & 44 & 36 & 20 & 62 & 23 & 45 & 21 & 52 & 9 & 18 & $\mathbf{0}$ & 10 & 24 & 445 & 100 \\
\hline No. of genera & 1 & 4 & 5 & 6 & 3 & 4 & 3 & 3 & 5 & 6 & 6 & 3 & 3 & 0 & 2 & 4 & & \\
\hline No. of species & 1 & 6 & 7 & 8 & 5 & 4 & 7 & 4 & 7 & 6 & 9 & 3 & 6 & 0 & 2 & 5 & & \\
\hline Total CFUs & \multicolumn{2}{|c|}{38} & \multicolumn{2}{|l|}{87} & \multicolumn{2}{|l|}{56} & \multicolumn{2}{|l|}{85} & \multicolumn{2}{|l|}{66} & \multicolumn{2}{|l|}{61} & \multicolumn{2}{|l|}{18} & \multicolumn{2}{|l|}{34} & \multicolumn{2}{|l|}{445} \\
\hline Total genera (18) & \multicolumn{2}{|l|}{4} & \multicolumn{2}{|l|}{\begin{tabular}{|l}
9 \\
\end{tabular}} & \multicolumn{2}{|l|}{6} & \multicolumn{2}{|l|}{5} & \multicolumn{2}{|l|}{10} & \multicolumn{2}{|l|}{7} & \multicolumn{2}{|l|}{3} & \multicolumn{2}{|l|}{5} & \\
\hline Total species (32) & \multicolumn{2}{|l|}{6} & \multicolumn{2}{|l|}{14} & \multicolumn{2}{|l|}{9} & 11 & & 12 & & 10 & & 6 & & 6 & & & \\
\hline
\end{tabular}

The quantitative assay of the three enzymes for high-producers were performed in submerged fermentation using sucrose-free $\mathrm{Cz}$ broth. Aspergillus was superior in the production of the three enzymes with the potent strains were A. terreus AUMC 14287 for CMCase and avicellase, and A. terreus AUMC 14278 for pectinase. Almost similar results were reported by (Sunitha et al. 2013) who found that $62.0 \%$ and $32.0 \%$ of their tested endophytic isolates were positive for pectinase and cellulase respectively, however, their tested fungi were isolated from plants differ from ours. In another study of cellulase activity of fungi inhabiting salt marshes, 100\% of the tested isolates showed cellulolytic activity (Gessner 1980), while 66.0 $\%$ of fungi isolated from Brucea javanica could produce cellulase enzyme (Choi et al. 2005). The main endophytic fungi work in literature involves screening for secondary metabolites of antimicrobial and antioxidant activity. Not many explored the possibility of endophytic fungi as industrially essential biotechnological reservoirs of enzymes.

Cellulases have been widely used in agricultural, biofuel, detergent, fermentation, food, paper pulp, and textile industries (Kuhad et al. 2011). Screening of the isolates for cellulase activity was attempted with a view of endophytes penetrating the plant tissue through the lignocellulosic wall with the help of the hydrolytic enzymes, cellulases being predominant among them (Carroll \& Petrini 1983). In addition, it was reported that some endophytes might behave as latent saprophytes, and when the host dies, they use these enzymes for tissue degradation to obtain nutrients (De Aldana et al. 2013). Studies also estimated that microbial pectinase accounts for $25 \%$ of global food and industrial enzymes revenues and is increasingly growing in the market (Oumer 2017). In addition, enzymes are a well-established global industry that is expected to hit USD 6.3 billion in 2021 (Oumer \& Abate 2018).

The current results revealed that $78.3 \%$ of total isolates could hydrolyze pectin in submerged fermentation, of which $77.14 \%$ were Aspergillus isolates, $76.9 \%$ Alternaria, and $86.95 \%$ Fusarium showed positive results. The present findings were in concurrence with those of Sunitha et al. (2013) 
who reported that $62 \%$ of their tested fungi were pectinase producers, and better than results obtained by Shubha \& Srinivas (2017) who found that $30 \%$ of their tested fungi had the pectinolytic activity. However, Choi et al. (2005) have reported that pectinase production was absent in all the endophytic fungi of Brucea javanica.

Aspergillus species was superior in pectinase activity with A. terreus being the potent strain giving rise to $163.244 \mathrm{IU} / \mathrm{ml}$ which is more than the result of pectinase production (106.7 $\mathrm{IU} / \mathrm{ml}$ ) produced by Aspergillus sp. Gm (KC et al. 2020) and much more the outcome of pectinase production $(1.524 \mathrm{IU} / \mathrm{ml}$ ) stated by (Sopalun \& Iamtham 2020) from endophytic fungi isolated from Thai Orchids.

The production of plant cell-wall digestive enzymes is now a focus of current research. Many such researches have been done into the production of cellulase and pectinase due to the huge number of application scenarios of these enzymes (Jalis et al. 2014, Edor et al. 2018, Ismail et al. 2018, Li et al. 2020, Xue et al. 2020).

Table 2 Pectinase production and activity of some endophytic fungi.

\begin{tabular}{|l|l|l|l|l|}
\hline \multirow{2}{*}{ Fungal species } & \multirow{2}{*}{ AUMC no. } & $\begin{array}{l}\text { Pectinase } \\
\text { Glucose } \\
\text { g/l }\end{array}$ & $\begin{array}{l}\text { Production } \\
\text { IU/ml }\end{array}$ & $\begin{array}{l}\text { Activity } \\
\text { IU/ml/min }\end{array}$ \\
\hline Aspergillus flavus & & 19.27 & 107.063 & 147.8 \\
\hline A. flavus & 14274 & 27.82 & 154.555 & 213.4 \\
\hline A. fumigatus & 14289 & 27.44 & 152.438 & 210.5 \\
\hline A. terreus* & 14283 & $\mathbf{2 9 . 4}$ & $\mathbf{1 6 3 . 2 4 4}$ & $\mathbf{2 2 5 . 4}$ \\
\hline A. terreus & $\mathbf{1 4 2 7 8}$ & 26.34 & 146.326 & 202.0 \\
\hline A. terreus & 14287 & 26.0 & 144.814 & 200.0 \\
\hline A. terreus & 14293 & 24.14 & 134.103 & 185.2 \\
\hline Cladosporium exile & 14279 & 23.91 & 132.846 & 183.4 \\
\hline Curvularia spicifera & 14294 & 23.6 & 131.016 & 180.9 \\
\hline C. spicifera & 14276 & 29.0 & 161.255 & 222.7 \\
\hline Fusarium solani & 14273 & 23.3 & 129.472 & 178.8 \\
\hline F. solani & 14277 & 21.6 & 119.954 & 165.6 \\
\hline Macrophomina phaseolina & 14292 & 23.253 & 129.185 & 178.4 \\
\hline M. phaseolina & 14272 & 23.0 & 127.854 & 176.5 \\
\hline Penicillium olsonii & 14275 & 23.73 & 131.843 & 182.0 \\
\hline Yeast sp. & 14295 & 24.85 & 138.066 & 190.7 \\
\hline Yeast sp. & 14289 & 22.9 & 127.275 & 175.8 \\
\hline
\end{tabular}

* The highest producer showed in bold

Table 3 Endoglucanase (CMCase) production and activity of some endophytic fungi.

\begin{tabular}{|c|c|c|c|c|}
\hline \multirow[b]{2}{*}{ Fungal species } & \multirow[b]{2}{*}{ AUMC no. } & \multicolumn{3}{|c|}{ Endoglucanase (CMCase) } \\
\hline & & $\begin{array}{l}\text { Glucose } \\
\text { g/l }\end{array}$ & $\begin{array}{l}\text { Production } \\
\text { IU/ml }\end{array}$ & $\begin{array}{l}\text { Activity } \\
\text { IU/ml/min }\end{array}$ \\
\hline Aspergillus flavus & 14274 & 0.41 & 2.282 & 3.15 \\
\hline A. fumigatus & 14283 & 0.3 & 1.684 & 2.32 \\
\hline A. terreus & 14278 & 1.9 & 10.623 & 14.7 \\
\hline A. terreus* & 14287 & 2.874 & 15.966 & 22.0 \\
\hline A. terreus & 14280 & 2.68 & 14.895 & 20.6 \\
\hline
\end{tabular}


Table 3 Continued.

\begin{tabular}{|l|l|l|l|l|}
\hline \multirow{2}{*}{ Fungal species } & \multirow{2}{*}{ AUMC no. } & $\begin{array}{l}\text { Endoglucanase (CMCase) } \\
\text { Glucose } \\
\text { g/l }\end{array}$ & $\begin{array}{l}\text { Production } \\
\text { IU/ml }\end{array}$ & $\begin{array}{l}\text { Activity } \\
\text { IU/ml/min }\end{array}$ \\
\hline A. terreus & & 1.47 & 8.164 & 11.3 \\
\hline A. terreus & 14282 & 1.9 & 10.579 & 14.6 \\
\hline A. terreus & 14284 & 1.5 & 8.328 & 11.5 \\
\hline A. terreus & 14285 & 1.0 & 5.575 & 7.7 \\
\hline Clonostachys rosea & 14288 & 0.24 & 1.332 & 1.84 \\
\hline Curvularia spicifera & 14291 & 1.3 & 7.167 & 9.9 \\
\hline C. spicifera & 14276 & 1.39 & 7.711 & 10.65 \\
\hline Fusarium oxysporum & 14273 & 0.757 & 4.206 & 5.8 \\
\hline F. solani & 14290 & 0.7 & 3.910 & 5.4 \\
\hline
\end{tabular}

* The highest producer showed in bold

Table 4 Avicellase production and activity of some endophytic fungi.

\begin{tabular}{|l|l|l|l|l|}
\hline \multirow{2}{*}{ Fungal species } & \multirow{2}{*}{ AUMC no. } & $\begin{array}{l}\text { Avicellase } \\
\text { Glucose } \\
\text { g/l }\end{array}$ & $\begin{array}{l}\text { Production } \\
\text { IU/ml }\end{array}$ & $\begin{array}{l}\text { Activity } \\
\text { IU/ml/min }\end{array}$ \\
\hline Aspergillus flavus & & 4.213 & 23.405 .5 & 35.55 \\
\hline A. fumigatus & 14274 & 4.232 & 23.512 & 35.71 \\
\hline A. terreus & 14283 & 4.049 & 22.496 & 34.17 \\
\hline A. terreus & 14278 & $\mathbf{5 . 6 7 2}$ & $\mathbf{3 1 . 5 1}$ & $\mathbf{4 7 . 8 7}$ \\
\hline A. terreus & $\mathbf{1 4 2 8 7}$ & 4.418 & 24.51 & 37.23 \\
\hline A. terreus & 14280 & 3.706 & 20.588 & 31.3 \\
\hline A. terreus & 14282 & 3.671 & 20.395 & 30.98 \\
\hline A. terreus & 14284 & 3.876 & 21.53 & 32.71 \\
\hline A. terreus & 14285 & 4.907 & 27.258 & 41.41 \\
\hline Clonostachys rosea & 14288 & 3.466 & 19.258 & 29.25 \\
\hline Curvularia spicifera & 14291 & 3.592 & 19.958 & 30.32 \\
\hline C. spicifera & 14276 & 3.782 & 21.008 & 31.91 \\
\hline Fusarium oxysporum & 14273 & 3.085 & 17.139 & 26.0 \\
\hline F. solani & 14290 & 3.709 & 20605 & 31.3 \\
\hline
\end{tabular}

* The highest producer showed in bold

\section{Conclusion}

The current research investigates the ecology of endophytic fungi in wild medicinal plants in the New Valley Governorate, Egypt and determines their ability to produce hydrolyzing enzymes. The study managed to retrieve a total of 120 fungal isolates from just eight plants, indicating their widespread distribution. The study also confirmed the ability of these fungal isolates to produce pectinase and cellulase. The potent strains of Aspergillus was the superior in enzymes production with A. terreus AUMC 14287 for CMCase and avicellase, and A. terreus AUMC 14278 for pectinase. The study further highlights the promising ability to produce extracellular enzymes by endophytic fungi, thus showing the importance of further analysis to resolve key issues in this area. 


\section{Conflict of interests}

The authors have not declared any conflict of interests.

\section{References}

Al-Bedak OA, Abdel-Sater MA, Abdel-Latif AMA, Abdel-Wahab D. 2020 - Aspergillus creber and A. keveii, two new records as endophytes from wild medicinal plants in Egypt. Journal of Multidisciplinary Sciences 2, 1-9.

Al-Bedak OA, Sayed RM, Hassan SH. 2019 - A new low-cost method for long-term preservation of filamentous fungi. Biocatalysis and Agricultural Biotechnology 22, 101417.

Al-Snafi A. 2015 - The chemical contents and pharmacological effects of Anagallis arvensis-A review. International Journal of Pharmacy 5, 37-41.

Anwar F, Latif S, Ashraf M, Gilani AH. 2007 - Moringa oleifera: a food plant with multiple medicinal uses. Phytotherapy Research: An International Journal Devoted to Pharmacological and Toxicological Evaluation of Natural Product Derivatives 21, 17-25.

Bailey MJ, Biely P, Poutanen K. 1992 - Interlaboratory testing of methods for assay of xylanase activity. Journal of biotechnology 23, 257-270.

Booth C. 1971 - The genus Fusarium. Commonwealth Mycological Institute. Kew, Surrey 237 p.

Carbungco E, Pedroche N, Panes V, De la Cruz T. 2015 - Identification and characterization of endophytic fungi associated with the leaves of Moringa oleifera Lam, I International Symposium on Moringa 1158, 373-380.

Carroll G, Petrini O. 1983 - Patterns of substrate utilization by some fungal endophytes from coniferous foliage. Mycologia 75, 53-63.

Choi Y, Hodgkiss I, Hyde K. 2005 - Enzyme production by endophytes of Brucea javanica. J Agric Technol 1, 55-66.

De Aldana BRV, Bills G, Zabalgogeazcoa I. 2013 - Are endophytes an important link between airborne spores and allergen exposure? Fungal Diversity 60, 33-42.

de Hoog GS, Guarro J, Gené J, Figueras M. 2000 - Atlas of clinical fungi. Centraalbureau voor Schimmelcultures (CBS) $1126 \mathrm{p}$.

Domsch K, Gams W, Anderson T. 2007- Compendium of soil fungi. 1-672. IHW-Verlag, Eching, Germany $672 \mathrm{p}$.

Edor SP, Edogbanya OP, Kutshik JR. 2018 - Cellulase activity of Aspergillus niger in the biodegradation of rice husk. MOJ Biology and Medicine 3(3), 49-51

Ellis M. 1976 - More Dematiaceous Hyphomycetes.,(Commonwealth Mycological Institute: Kew, Surrey) $507 \mathrm{p}$.

Gessner R. 1980 - Degradative enzyme production by salt-marsh fungi. Botanica Marina 23, $133-139$.

Gherbawy Y, Gashgari R. 2014 - Molecular characterization of fungal endophytes from Calotropis procera plants in Taif region (Saudi Arabia) and their antifungal activities. Plant Biosystems-An International Journal Dealing with all Aspects of Plant Biology 148, $1085-1092$.

Hamayun M, Khan SA, Khan AL, Rehman G et al. 2010 - Gibberellin production and plant growth promotion from pure cultures of Cladosporium sp. MH-6 isolated from cucumber (Cucumis sativus L.). Mycologia 102, 989-995. 
Ismail MA, Moubasher AH, Mohamed RA, Al-Bedak OA. 2017 - Extremophilic fungi and chemical analysis of hypersaline, alkaline lakes of Wadi-El-Natrun, Egypt. International Journal of Technical Research and Science 1, 345-363.

Ismail MA, Moubasher AH, Mohamed RA, Al-Beddak OA. 2018 - Agro-industrial residues as alternative sources for cellulases and xylanases production and purification of xylanase produced by Aspergillus flavus AUMC 10331 isolated from extreme habitat. Current Research in Environmental \& Applied Mycology 8, 313-322.

Jalis H, Ahmad A, Khan S, Sohail M. 2014 - Utilization of apple peels for the production of plant cell-wall degrading enzymes by Aspergillus fumigatus MS16. J Anim Plant Sci 24, 64-67.

Kaur M, Kalia A. 2012 - Convolvulus arvensis: A useful weed. Int J Pharm Pharm Sci 4, 38-40.

KC S, Upadhyaya J, Joshi DR, Lekhak B et al. 2020 - Production, Characterization, and Industrial Application of Pectinase Enzyme Isolated from Fungal Strains. Fermentation 6 (59), 2-10.

Khairnar AK, Bhamare S, Bhamare H. 2012 - Calotropis procera: an ethnopharmacological update. Advance Research in Pharmaceuticals and Biologicals 2, 142-156.

Khan AL, Waqas M, Hussain J, Al-Harrasi A, Lee I-J. 2014 - Fungal endophyte Penicillium janthinellum LK5 can reduce cadmium toxicity in Solanum lycopersicum (Sitiens and Rhe). Biology and fertility of soils 50, 75-85.

Khan Marwat S, Khan EA, Baloch MS, Sadiq M et al. 2017 - Ricinus cmmunis: Ethnomedicinal uses and pharmacological activities. Pakistan journal of pharmaceutical sciences 30(5), $1815-1827$.

Khan R, Shahzad S, Choudhary MI, Khan SA, Ahmad A. 2007 - Biodiversity of the endophytic fungi isolated from Calotropis procera (Ait.) R. Br. Pakistan Journal of Botany 39, e2239.

Krishnamurthy YL, Naik SB, Jayaram S. 2008 - Fungal communities in herbaceous medicinal plants from the Malnad region, Southern India. Microbes and environments 23, 24-28.

Kuhad RC, Gupta R, Singh A. 2011 - Microbial cellulases and their industrial applications. Enzyme research 2011, 1-10.

Leslie J, Summerell B. 2006 - The Fusarium Laboratory Manual Blackwell Publishing. Ames, Iowa $382 \mathrm{p}$.

Li J-X, Zhang F, Jiang D-D, Li J et al. 2020 - Diversity of Cellulase-Producing Filamentous Fungi From Tibet and Transcriptomic Analysis of a Superior Cellulase Producer Trichoderma harzianum LZ117. Frontiers in Microbiology 11, 1617.

Miller GL. 1959 - Use of dinitrosalicylic acid reagent for determination of reducing sugar. Analytical chemistry $31,426-428$.

Moubasher AH. 1993 - Soil fungi in Qatar and other Arab countries. The Centre for Scientific and Applied Research, University of Qatar $568 \mathrm{p}$.

Moubasher AH, Ismail MA, Mohamed RA, Al-Bedak OA. 2016 - Xylanase and cellulase production under extreme conditions in submerged fermentation by some fungi isolated from hypersaline, alkaline lakes of Wadi-El-Natrun, Egypt. Journal of Basic \& Applied Mycology (Egypt) 7, 19-32.

Muhammad G, Hussain MA, Anwar F, Ashraf M, Gilani AH. 2015 - Alhagi: a plant genus rich in bioactives for pharmaceuticals. Phytotherapy research 29, 1-13.

Oumer OJ. 2017 - Pectinase: substrate, production and their biotechnological applications. International Journal of Environment, Agriculture and Biotechnology 2, 238761. 
Oumer OJ, Abate D. 2018 - Screening and molecular identification of pectinase producing microbes from coffee pulp. BioMed research international 2018, 1-7.

Patil MG, Pagare J, Patil SN, Sidhu AK. 2015 - Extracellular enzymatic activities of endophytic fungi isolated from various medicinal plants. Int J Curr Microbiol App Sci 4, 1035-1042.

Petrini O. 1991 - Fungal Endophytes of Tree Leaves. In: Andrews J.H., Hirano S.S. (eds) Microbial Ecology of Leaves. Brock/Springer Series in Contemporary Bioscience. Springer, New York, NY. 179-197.

Pitt JI. 1979 - The genus Penicillium and its teleomorphic states Eupenicillium and Talaromyces. Prabavathy D, Valli NC. 2012 - Screening for extracellular enzymes and production of cellulase by an endophytic Aspergillus sp., using cauliflower stalk as substrate. International Journal on Applied Bioengineering 6(2), 40-45.

Raviraja N. 2005 - Fungal endophytes in five medicinal plant species from Kudremukh Range, Western Ghats of India. Journal of Basic Microbiology: An International Journal on Biochemistry, Physiology, Genetics, Morphology, and Ecology of Microorganisms 45, 230-235.

Rodriguez R, White Jr J, Arnold AE, Redman aRa. 2009 - Fungal endophytes: diversity and functional roles. New phytologist 182, 314-330.

Samson R, Hoekstra E, Frisvad J, Filtenborg O. 2004 - Introduction to food and airborne fungi 7th ed. Utrecht: Centraal Bureau voor Schimmelcultures 389 p.

Schardl CL, Leuchtmann A, Spiering MJ. 2004 - Symbioses of grasses with seedborne fungal endophytes. Annu. Rev. Plant Biol. 55, 315-340.

Shubha J, Srinivas C. 2017 - Diversity and extracellular enzymes of endophytic fungi associated with Cymbidium aloifolium L. African Journal of Biotechnology 16, 2248-2258.

Simmons EG. 2007 - Alternaria: An Indentification Manual. Utrecht, The Netherlands: CBS Fungal Biodiversity Centre. 775 p.

Singh LP, Gill SS, Tuteja N. 2011 - Unraveling the role of fungal symbionts in plant abiotic stress tolerance. Plant signaling \& behavior 6, 175-191.

Sopalun K, Iamtham S. 2020 - Isolation and screening of extracellular enzymatic activity of endophytic fungi isolated from Thai orchids. South African Journal of Botany (2020), 1-7.

Strobel G, Daisy B, Castillo U, Harper J. 2004 - Natural products from endophytic microorganisms. Journal of Natural products 67, 257-268.

Sunitha V, Nirmala Devi D, Srinivas C. 2013 - Extracellular enzymatic activity of endophytic fungal strains isolated from medicinal plants. World Journal of Agricultural Sciences 9, 19.

Syed S, Fatima N, Kabeer G. 2016 - Portulaca oleracea L.: a mini review on phytochemistry and pharmacology. International journal of Biology and Biotechnology 13, 637-641.

Xue Y, Han J, Li Y, Liu J et al. 2020 - Promoting cellulase and hemicellulase production from Trichoderma orientalis EU7-22 by overexpression of transcription factors Xyr1 and Ace3. Bioresource Technology 296, 122355.

Zou W, Meng J, Lu H, Chen G et al. 2000 - Metabolites of Colletotrichum gloeosporioides, an endophytic fungus in Artemisia mongolica. Journal of Natural Products 63, 1529-1530. 
Appendix 1 Preliminary screening of pectinases and cellulases production by endophytic fungi recovered from leaves and roots of eight wild medicinal plants collected from El-Kharga Oasis, the New Valley Governorate, Egypt, during April 2018.

\begin{tabular}{|c|c|c|c|c|c|c|c|c|c|}
\hline \multirow{3}{*}{ Fungal species } & \multirow{3}{*}{ Number of isolates tested } & \multicolumn{8}{|c|}{ Preliminary screening } \\
\hline & & \multicolumn{4}{|c|}{ Pectinases } & \multicolumn{4}{|c|}{ Cellulases } \\
\hline & & Positive & $\mathbf{L}$ & $\mathbf{M}$ & $\mathbf{H}$ & Positive & $\mathbf{L}$ & $\mathbf{M}$ & $\mathbf{H}$ \\
\hline Acremonium & 2 & 2 & $\mathbf{1}$ & 1 & & 2 & 1 & & 1 \\
\hline Acremonium rutilum & 1 & 1 & 1 & & & 1 & 1 & & \\
\hline Acremonium sclerotigenum & 1 & 1 & & 1 & & 1 & & & 1 \\
\hline Alternaria & 26 & 20 & 14 & 6 & & 6 & 4 & 2 & \\
\hline A. alternata & 8 & 7 & 5 & 2 & & 2 & 2 & & \\
\hline A. brassicicola & 1 & 1 & & 1 & & & & & \\
\hline A. chlamydospora & 1 & 1 & & 1 & & 1 & 1 & & \\
\hline A. citri & 3 & 2 & 2 & & & & & & \\
\hline A. citri macularis & 2 & & & & & 2 & & 2 & \\
\hline A. longipes & 3 & 3 & 1 & 2 & & 1 & 1 & & \\
\hline A. tenuissima & 8 & 6 & 6 & & & & & & \\
\hline Aspergillus & 35 & 27 & 11 & 9 & 7 & 21 & 6 & 7 & 8 \\
\hline A. flavus & 9 & 7 & 3 & 2 & 2 & 4 & 1 & 2 & 1 \\
\hline A. fumigatus & 2 & 1 & & & 1 & 2 & & 1 & 1 \\
\hline A. parasiticus & 6 & 3 & 2 & 1 & & 2 & & 2 & \\
\hline A. terreus & 15 & 14 & 5 & 5 & 4 & 12 & 4 & 2 & 6 \\
\hline A. tubingensis & 1 & & & & & & & & \\
\hline Aspergillus AY-1 & 1 & 1 & 1 & & & 1 & 1 & & \\
\hline Aspergillus AY-2 & 1 & 1 & & 1 & & & & & \\
\hline Beauveria bassiana & 1 & 1 & 1 & & & & & & \\
\hline Chaetomium senegalense & 1 & 1 & 1 & & & & & & \\
\hline Cladosporium exile & 1 & 1 & & & 1 & 1 & & 1 & \\
\hline Clonostachys solani & 1 & 1 & 1 & & & 1 & & 1 & \\
\hline Curvularia spicifera & 2 & 1 & 1 & & & 2 & 2 & & \\
\hline Fusarium & 23 & 20 & 14 & 3 & 3 & 16 & 13 & $\mathbf{1}$ & 2 \\
\hline F. oxysporum & 13 & 11 & 8 & 2 & 1 & 11 & 10 & & 1 \\
\hline F. solani & 10 & 9 & 6 & 1 & 2 & 5 & 3 & 1 & 1 \\
\hline Macrophomina phaseolina & 7 & 3 & & & 3 & 3 & 2 & 1 & \\
\hline Penicillium olsonii & 1 & 1 & & & 1 & 1 & & 1 & \\
\hline Pseudo allescheria boydii & 1 & 1 & & 1 & & 1 & & & 1 \\
\hline Rhizopus microsporus & 1 & 1 & & 1 & & 1 & 1 & & \\
\hline Sarocladium kiliense & 1 & 1 & 1 & & & 1 & 1 & & \\
\hline Scopulariopsis fimicola & 1 & & & & & & & & \\
\hline Stemphylium botryosum & 5 & 5 & 3 & 2 & & 3 & 3 & & \\
\hline Verticillium fungicola & 1 & 1 & & 1 & & 1 & & & 1 \\
\hline Yeast spp. & 10 & 7 & 3 & 1 & 3 & 6 & 4 & 2 & \\
\hline Total isolates & 120 & 94 & 51 & 25 & 18 & 66 & 37 & 16 & 13 \\
\hline No. of genera & 17 & 16 & $\mathbf{1 0}$ & 8 & 8 & 14 & 9 & 6 & 5 \\
\hline No. of species & 31 & 28 & 17 & 15 & 9 & 23 & 14 & 9 & 8 \\
\hline
\end{tabular}

Note: $\mathrm{H}=$ high producers: $\geq 20 \mathrm{~mm}, \mathrm{M}=$ moderate: $11-19 \mathrm{~mm}, \mathrm{~L}=<11 \mathrm{~mm}$ 